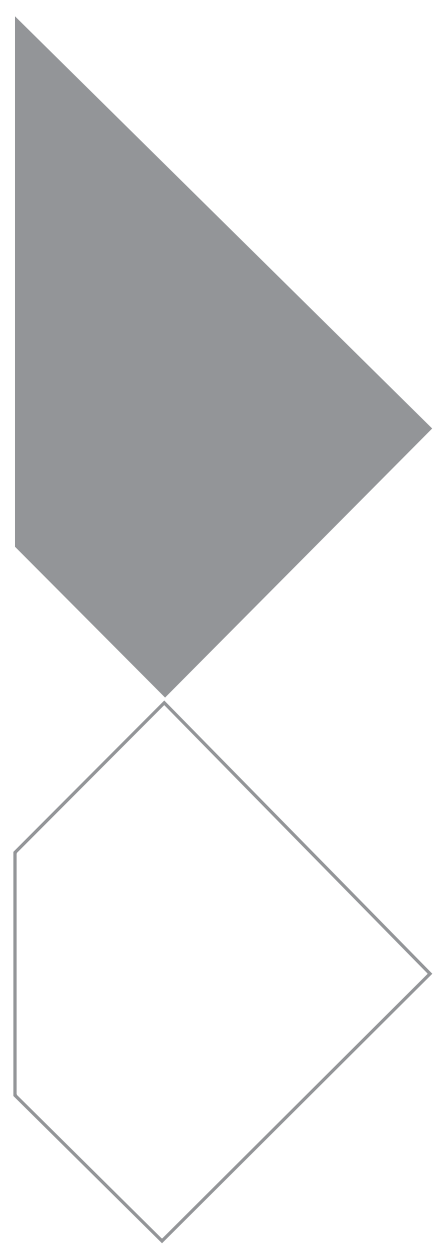

\title{
Circulando imagens, circulam antropologias: mulheres, políticas do corpo e espetacularização da vida
}

\author{
Rosamaria Carneiro \\ Doutora em Ciências Sociais (Unicamp) \\ Professora da Universidade de Brasília \\ Brasília, Distrito Federal, Brasil \\ rosagiatti@yahoo.com.br
}

\begin{abstract}
Resumo Este trabalho se dispõe a pensar sobre as noções de pessoa, corpo feminino e sexualidade a partir da circulação de imagens de e sobre partos no mundo virtual, mais especialmente, nas redes sociais. Dessa maneira, tem por mola propulsora o registro imagético, que tanto movimenta a produção da antropologia quanto opera como metacrítica, nos fazendo pensar, por último, sobre a sua própria tessitura. Em que pese não empreender um exercício de antropologia visual, parte de imagens e de sua circulação para refletir sobre a própria produção do fazer etnográfico, sobretudo, a partir das discussões sobre autoridade etnográfica. Nesses jogos de imagens de parto e de corpos de mulheres, percebe-se a profusão de leituras e de políticas do corpo feminino e da parturição, que tanto conformam outras imagens quanto espetacularizam outras tantas já consolidadas e ainda vigentes. Nesse sentido, a ideia central é refletir sobre gênero, ativismo, crítica social, saúde sexual e reprodutiva e noção de pessoa na contemporaneidade a partir do que se vê na internet, mas também se lê e já se escutou; pensando com e através de outras linguagens e idiomas.
\end{abstract}

Palavras-chave: imagens, antropologia, parto, sexualidade, pessoa.

\section{Entre cenas e dos relatos às imagens}

E

m minha tese de doutoramento, etnografei experiências femininas de parto humanizado na contemporaneidade, procurando pensar corpo, pessoa e sexualidade (Carneiro, 2011). Por parto humanizado pode-se compreender o parto com o mínimo de intervenções possíveis ou o "mais natural", porém, como se depreende do artigo de Diniz (2005), múltiplos ou polissêmicos podem ser os significados de "parto humanizado". Por parto humanizado pode-se entender o movimento de mulheres e de profissionais de saúde em torno da crítica de cesáreas e de procedimentos médicos invasivos; pode ser a demanda por relações mais horizontalizadas na assistência; observância aos aspectos culturais e regionais daquela que pare; pode ser o parto em que todos os procedimentos são informados e consentidos pela gestante ou do qual o pai pode participar; pode ser o parto com ou sem nenhuma intervenção; o parto propalado nas atuais políticas governamentais de saúde; ou o que tem embasado discussões sobre a formação dos profissionais de saúde.

Enquanto discurso, gera uma rede de articulação de pessoas que criticam o excesso de cesáreas, de tecnologia e farmacologia nas cenas de parto brasileiras. Para isso, parti de relatos e da observação participante de dois grupos de preparo para o parto humanizado em São Paulo, no período de 2008 a 2010. Já nessa época, no entanto, outra 
frente de pesquisa se anunciava, quando me deparava com os usos das internet nesse universo, posto que chamava-me a atenção tanto o cyberativismo quanto as narrativas de si que as mulheres adeptas dessa filosofia faziam em blogs, listas de discussão, sites e redes sociais.

Em razão de seguir em contato com o universo do parto humanizado, mais especificamente através do FB (Facebook), o uso recente da autoimagem no espaço virtual tem me impelido a refletir sobre sua potencialidade para mobilização política, circulação de outras leituras do corpo feminino e materno e, por fim, ou simultaneamente, sobre uma certa espetacularização da vida.

Diante disso, incitada a refletir sobre tais práticas, tratarei de recortar e de descrever algumas dessas situações virtuais-imagéticas, com o objetivo de problematizar a sua circulação, reciprocidade e reconhecimento grupal e, ao final, desenhos contemporâneos da noção de pessoa, tendo como arcabouço teórico o pensamento de Dumont $(1966,1985)$ e daqueles que nele se inspiraram para pensar a sociedade brasileira (Velho, 1978, 1999; Duarte, 2003, 2004; Salem, 2007).

\section{Circulando a autoimagem... circulam afetos, reconhecimento e ativismo}

Durante minha etnografia, ao acompanhar listas de discussão online sobre parto e os posicionamentos das mulheres que as compunham, pude perceber que as mulheres assinavam os e-mails encaminhados da seguinte forma:

(Nome da mulher), mãe de (Nome da criança), nascido de parto domiciliar/parto humanizado hospitalar, parto domiciliar ou $\mathrm{VBAC}^{1}$

Essa marcação, mãe de fulano, que nasceu de tal tipo de parto, transparecia ser, a um só tempo, uma tentativa de obter o reconhecimento grupal, ou seja, de igualar-se ou se inserir no grupo, partilhando de códigos, como também um modo de se diferenciarem umas das outras a partir de suas trajetórias gestacionais e de parturição. Havia as que tinham parido em casa, geralmente as mais respeitadas porque as mais corajosas ou as mais confiantes; as mulheres de casas de parto; as dos hospitais humanizados; as que passaram por algumas intervenções com ou sem o consentimento; e, por último, as "cesareadas" (Carneiro, 2011), entre outras caracterizações.

Se, entre 2008 e 2010, percebia que essas assinaturas operavam como uma forma de pertencimento ao grupo, nos últimos anos, depois de concluída minha tese, percebo que outros artefatos circulam na internet com o mesmo objetivo. Nas redes sociais, circulam fotografias e vídeos de parto, caseiros ou profissionais, com o objetivo de reconhecerem a si mesmas e de narrarem suas histórias, aproximando-se umas das outras, mas também se distanciando. E, assim, não somente a escrita estabelece vínculos, mas também as imagens.

Para que se possa ter uma ideia do que ora trago à tona, vale recuperar um acontecimento interessante. Em 18 de março de 2012, o vídeo de parto do primeiro filho da terapeuta ocupacional Sabrina Ferigatto contou com 1,8 milhões de acessos entre o FB e o "site youtube". Ferigatto, que é adepta do ideário da humanização do nascimento e uma das coordenadoras de um grupo de preparo, depois de ter vivido um parto domiciliar e de tê-lo registrado em vídeo, colocou-o em circulação na internet e, em um curto espaço de tempo, os seus íntimos 14 minutos tornaram-se recorde de público e de acessos.

Pouco depois disso, em grupos abertos e fechados sobre parto humanizado no FB e em perfis de FB de mulheres que havia conhecido durante a pesquisa de doutorado, outros tantos vídeos do próprio parto passaram a circular e a serem publicitados. Nessa mesma época, soube por uma amiga cineasta, que vivia em Londres, que as filmagens de parto e sua divulgação não eram uma particularidade das brasileiras, pois, entre as inglesas, já existia inclusive um nicho profissional orientado a esse tipo de captação de imagens.

Dessa forma, poderíamos pensar que já não basta mais o médico e as enfermeiras, um cinegrafista também pode compor as cenas de parto. Isso, nas palavras de Ferigatto, desde que respeite a ressalva de que "a mãe não pode te sentir lá”. ${ }^{2}$ Ou seja, ele não pode e nem deve atrapalhar o trabalho de parto daquela mulher. De um vídeo, tornaram-se muitos. Foi tamanha a repercussão da profusão de imagens, a princípio íntimas, que o que parecia da ordem do privado ganhou desenho de público.

Nesses vídeos, pode-se assistir banheiras cheias de água, mulheres gemendo, chorando, sendo amparadas por seus maridos, acompanhadas de doulas, médicas ou obstetrizes. Crianças e animais também entram em cena expondo o ambiente doméstico, assim como as emoções mais incontroláveis, o grito, o

1. Vaginal Birth after Cesarian Section, uma sigla êmica muito usada nos escritos das adeptas do parto humanizado.

2. Disponível em: <http://g1.globo.com/sp/campinas-regiao/noticia/2012/03/video-de-parto-domiciliar-feito-em-campinas-vira-sucesso-nainternet.html>. Acesso em: 13 out. 2013. 
choro, o medo, a volúpia. É certo que as imagens são editadas, mas, ainda assim, trazem muito do que há de íntimo nesse universo. Corpos nus, seminus, maridos amparando, maridos perdidos, feições de dor e de prazer. Tudo isso, hoje, está a um simples "click" e tudo no "face".

Em minha leitura, essa troca e circulação de imagens entre as adeptas do parto "mais natural" poderiam ser pensadas a partir da necessidade de reconhecimento e de pertencimento a um grupo. Tratar-se-ia, por esse prisma, de um reconhecimento entre elas, entre iguais, para que reconheçam umas às outras como mulheres de um só grupo; porém, também entre diferentes e, por contraste, ao marcar uma linha divisória entre quem pertence e quem não partilha desse imaginário de parto; mas também um reconhecimento no interior do próprio grupo, ao diferenciarem-se em razão do tipo de parto vivido, ou seja, parto domiciliar (PD); parto vaginal depois de cesárea (VBAC); parto natural hospitalar (PNH); e casa de parto $(\mathrm{CP})$, entre outras siglas e denominações (Carneiro, 2011). É nesse jogo que as fotografias e as imagens em geral ingressam como o objeto que coloca a noção de pessoa em circulação e em relação social. E, assim, a socialidade se vê tecida a partir do objeto, rendando pessoa e coisa, sugerindo o que já apontava Appadurai, em A vida social das coisas (2008).

Nessa esteira, se os vídeos caseiros de parto foram, por uma fase, "a moda" nas redes sociais, por ocasião do lançamento do documentário "O renascimento do parto", de Érica de Paula e Eduardo Chauvet, em 2013, foi a vez de outro fenômeno imagético-virtual envolver as mulheres que não querem uma cesárea e buscam um parto "mais natural". Para que se possa entender melhor a que me refiro, vale recuperar o ocorrido às vésperas da chegada da película aos cinemas.

Na semana de estreia, podia-se usar um aplicativo do FB para inserir a própria imagem no cartaz que divulgava o filme e, assim, também tornar-se protagonista da obra. Foi impressionante o número de mulheres a trocar suas fotos pessoais de perfil por uma capa personalizada do filme. Nos grupos das redes sociais dos quais participo, aquelas que não encontravam o modo de fazê-lo pediam conselhos e dicas para as demais. E, assim, mais uma vez reconheciam a si mesmas e às outras, aproximando-se em razão do filme e diferenciando-se das não adeptas, desenhando assim uma noção de pessoa derivada de algo coletivo, grupal e hierarquizante, talvez mais próxima de uma perspectiva relacional do que individualista (Dumont, 1985).

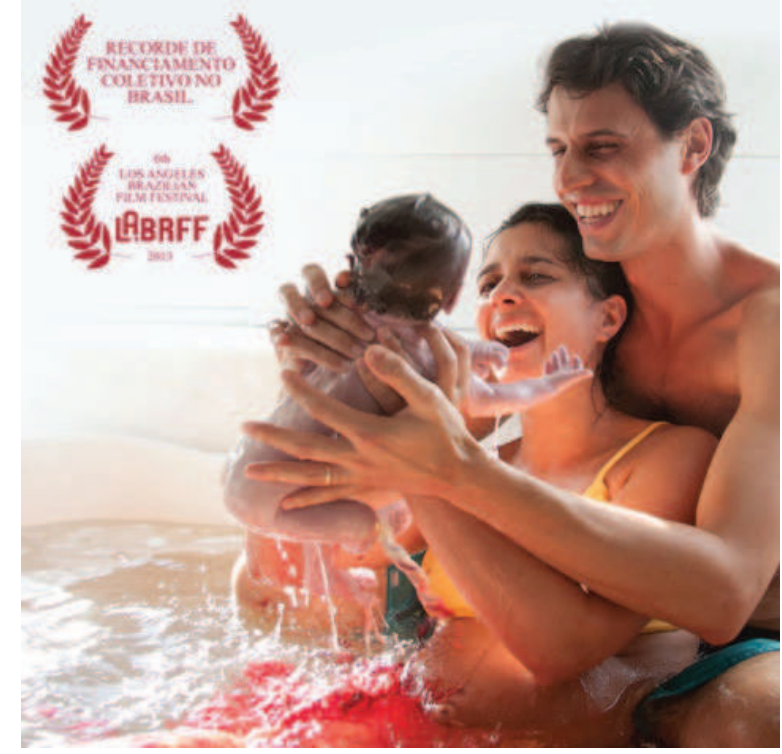

wWw.orenascimentodoparto.com.br

Vale, nesse sentido, também recordar que um pouco antes, em junho de 2012, por ocasião da "Marcha nacional do parto em casa", ${ }^{3}$ ato que ocorreu depois de o Conselho Regional de Medicina do Rio de Janeiro (CREMERJ) ter se posicionado contra o parto domiciliar, muitas dessas mesmas mulheres já haviam trocado suas imagens de perfil pela logomarca que aparece abaixo. Essa era/foi uma imagem que as identificava enquanto partes de uma mesma causa e, assim, gerava pertença. Ao usá-la e empregá-la em seus perfis, eram conformadas por uma não individualidade e por algo englobante, assim como a família para as camadas populares, como pensado por Duarte ao escrever sobre a figura do nervoso (1986). Eram lidas pela mesma imagem e, desse modo, por uma ideia/ethos e não mais pelo eu individualista e igualitário, diluído nessa esteira.

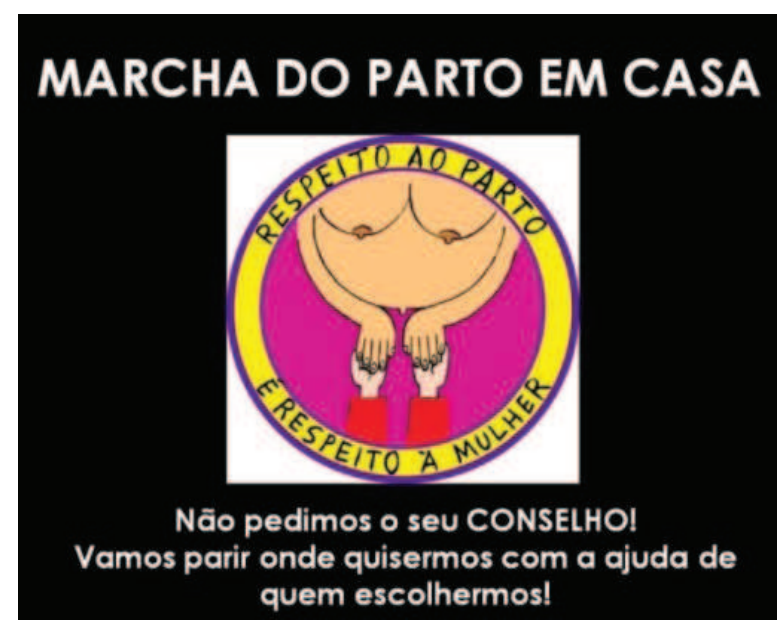

www.coisademae.com 
Essa noção de pessoa parece depender das/os outras/os e das relações estabelecidas do universo do parto humanizado - aqui entendido enquanto ideário e/ou ethos -, mas, ao mesmo tempo, também destaca a própria experiência, algo da ordem do individual. Essa leitura sinalizaria uma oscilação entre o "individualismo" e uma perspectiva mais relacional - para não dizer "holista" - de pessoa (Dumont, 1985).

Nos anos de 1960, foram publicadas as análises de Louis Dumont sobre a noção de pessoa, que, como sabido, depois de sua etnografia da sociedade indiana, passou a trabalhar com a classificação de sociedades holistas/sociedades individualistas. Nas primeiras, seriam encontrados os modelos mais abrangentes ou totalizadores da ideia de pessoa, enquanto nas segundas, como a capitalista ocidental, a ideologia moderna de homem, na qual a parte vem descolada da noção de todo. Esses estudos, pouco a pouco, a partir da década de 1970, atingiram a antropologia brasileira, dando margem a trabalhos importantes sobre a noção de pessoa em nossa sociedade, como os de Duarte (1986) sobre a doença nervosa entre as classes trabalhadoras, a partir da grade mais relacional; de Velho (1998), sobre as camadas médias cariocas, uso de drogas e cidades; e de Salem (2007), que analisou a noção de pessoa entre os "casais grávidos" envolvidos com o projeto denominado "Dois é um", sobre um parto natural daquela época.

Percebo que as adeptas do parto humanizado, assim como as mulheres etnografadas por Salem, advêm de camadas médias, mas, de maneira diferente da antropóloga carioca, tendo a pensar, considerando a teoria de Dumont, numa acepção "mista de pessoa" (Carneiro, 2011). De um lado, percebo que é o todo que determina a parte, o ideário do parto humanizado opera como organizador de lugares sociais e determina status e pessoas, como se vê a partir do compartilhamento de imagens e da criação de hierarquias internas que diferenciam umas mulheres das outras. Por outro lado, no entanto, persistem as características do "individualismo" descrito por Dumont, quando se constata o anseio por uma conformação também individual de si e da própria experiência e, assim, por "um parto todo seu" (Carneiro, 2011).

Diante disso, pode-se pensar que, ao circularem imagens, circulam coisas e circulam pessoas e que, por meio dessa circulação, estabelecem-se laços sociais e processos de diferenciação, que ora hierarquizam, ora igualam pessoas e objetos nesse universo do parto "mais natural".
A internet é uma grande ferramenta de comunicação no universo da humanização do parto. Muitas mulheres tomam conhecimento e trocam informações por meio de blogs, sites, listas de discussão e, agora, pelo FB. Por isso, o mundo virtual funciona como uma rede social e afetiva entre as mulheres e os profissionais de saúde (Carneiro, 2011), também para mobilização e para articulação política.

Para a organização e divulgação da "Marcha do parto em casa", que aconteceu em praticamente todas as capitais brasileiras, no dia 17 de junho de 2012, imagens de barrigas à mostra e pintadas, de crianças, de pais e de mulheres pelas ruas, carregando faixas em defesa do parto domiciliar, entraram em circulação. Cartazes com dizeres "O parto é nosso", "Eu nasci em casa" e "Pelo parto em casa" ocuparam avenidas famosas como, por exemplo, a Avenida Paulista, em São Paulo, e depois foram postos em cena nas redes sociais.

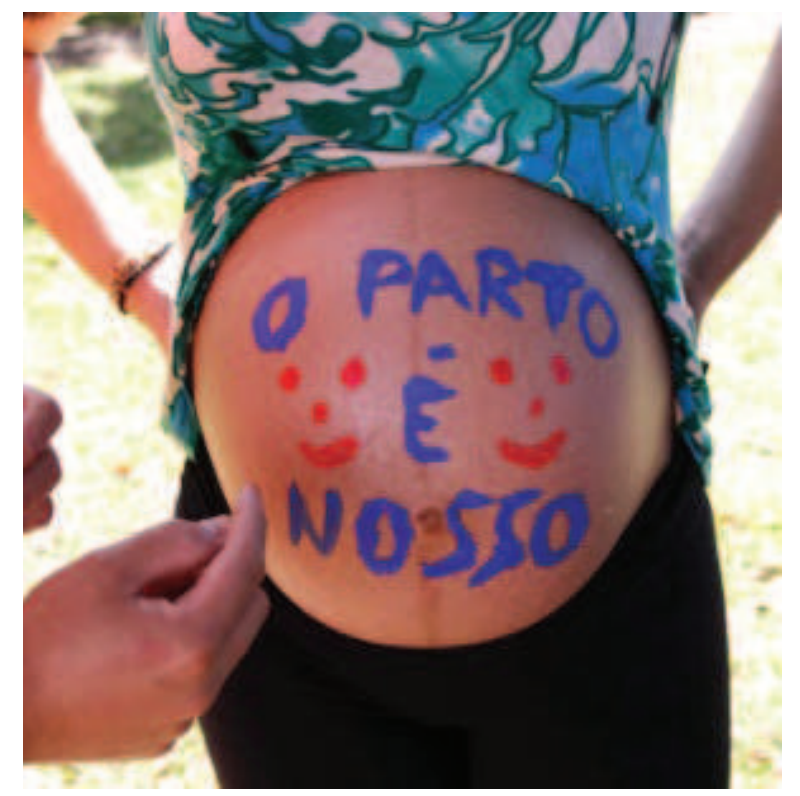

www.cebes.org.br

Para a realização e divulgação do documentário "Violência Obstétrica" (2013), de Bianca Zorzam, Ligia Moreiras Sena, Ana Carolina Franzon, Kalu Brum e Armando Rapchan, ${ }^{4}$ o mundo virtual também demonstrou ser uma importante ferramenta. Feito a partir de depoimentos pessoais, gravados com celular ou webcam, resultou numa mostra de imagens pessoais de denúncia e de mobilização política. ${ }^{5}$ Esse documentário circulou nas redes sociais e de perfil em perfil do FB, mobilizando mulheres para dele participarem; mas também, quando pronto, para assistir a ele; e por últi-

4. Pode ser assistido em: <http://www.youtube.com/watch?v=egOuvonF25M>

5. Congresso Fazendo Gênero 10. Desafios Atuais dos Feminismos. Florianópolis, 16 a 20 de setembro de 2013. UFSC. Para mais: <www. fazendogenero.ufsc.br> 
mo, recentemente, depois de ter ganhado um prêmio em um congresso feminista de renome no Brasil.

Essa necessidade talvez pudesse ser compreendida à luz do que escreve Silva (2011) resenhando Marc Augé (2010), sobre nossos tempos e suas particularidades, senão vejamos:

Expressando-se pelas migrações, práticas de turismo, mobilidades profissionais, mas igualmente pela instantaneidade da comunicação, pela intensa circulação de imagens, produtos e informações, a mobilidade sobremoderna guardaria relação com um mundo pautado por valores como "desterritorialização" e "individualismo". Contudo, este mesmo mundo - fluido, movimentado, conectado, mutante - também carrega em seu bojo exemplos de sedentarismos, de reivindicações de territorialidades, de práticas gregárias. (p. 154-155)

Isso posto, haveria, em fase de tanta diluição, também o desejo de pertencimento a um todo que nos diga quem somos e, por isso, práticas gregárias, como as expostas em tela, a partir do caso das adeptas do parto humanizado. Essa talvez também pudesse ser uma leitura das imagens que operam como o que mobiliza atos/marchas/passeatas e que, depois, ilustra a participação de tais mulheres nesses acontecimentos públicos. Dessa forma, as fotografias e os vídeos tanto agenciam esse todo que inscreve a noção de pessoa, como, em seguida, também o reafirmam e o reproduzem.

\section{Imagens e outras políticas do corpo feminino}

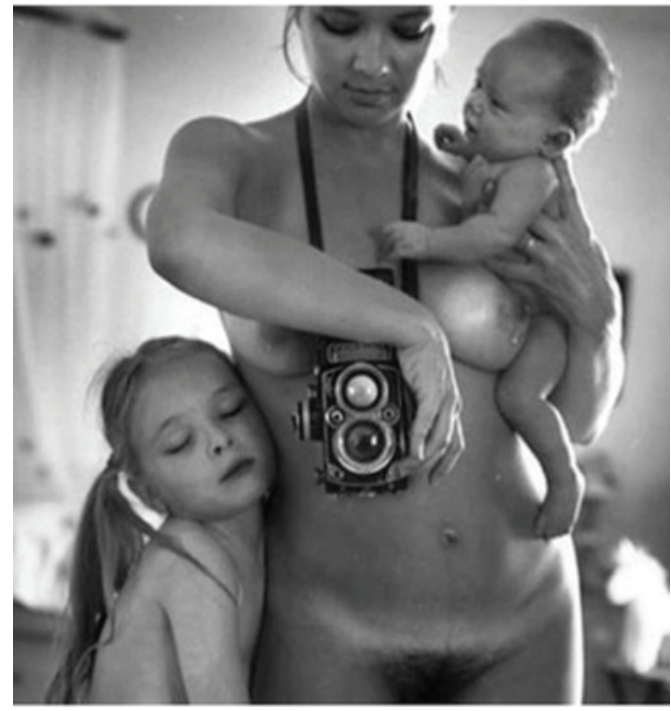

www.vilamamifera.com
Essa imagem foi inicialmente postada em um blog sobre "maternidade ativa" e experiências de parto humanizado, em 29 de julho de 2013. Contudo, em seguida, rapidamente conquistou território nas redes sociais. A imagem, de uma só vez, parece trazer à tona a nudez, a maternidade, uma estética e uma aposta política. Uma mulher bela, muito à vontade, fotografa a si e aos filhos, juntos e nus, e, assim, busca pôr em questão a nudez e as representações de corpo feminino e materno na atualidade. O post, em minha leitura, propositadamente, tinha por título "Nem toda nudez será castigada?"1 e carregava como texto um pouco do que abaixo transcrevo:

Quando estava grávida, ganhei da minha avó vários pijamas. Fiquei embasbacada diante daquelas peças de roupa. Fui criada em uma família cuja nudez nunca fora castigada. Lá em casa as pessoas nunca fecharam a porta do banheiro, seja para fazer cocô ou xixi, seja para tomar banho. [...] Para mim um corpo nu é apenas um corpo nu. O que me incita desejo é mais a atitude do que as formas em si. Desde que Miguel nasceu tomamos banho juntos. [...] Ali no banho ele percebeu que éramos diferentes: que homens têm pinto, mulheres vagina. Acredito que a nudez, na nossa sociedade, ainda é um grande tabu. Muito embora as roupas estejam cada dia mais curtas, os corpos mais expostos, as revistas femininas exibindo corpos nus, a nudez ainda é permitida quando usada para estimular e despertar a sexualidade, a sensualidade. [...] Essa sexualidade é, por sua vez, entendida como para servir aos desejos do homem. Quando a nudez é apenas uma nudez, como da moça da foto, quando um seio que alimenta não serve para seduzir, quando uma vagina está funcionando não para acolher um membro masculino, mas para trazer uma vida, há uma quebra na ordem social. (Grifo meu)

Kalu Brum, a mulher que aparece na foto, é jornalista, blogueira e doula. Teve um parto domiciliar e escreve no Blog Mamíferas, no qual muitas informações sobre humanização do nascimento têm sido divulgadas. Vê-se, a partir de suas linhas, a defesa de outra imagem de nudez e de corpo feminino, não necessariamente orientados à satisfação sexual masculina e que, justamente por assim se anunciarem, geram desconforto social.

A autora chama atenção para o descompasso entre a massiva exibição da nudez feminina em pequenas roupas, revistas masculinas e publicidade cotidiana e, de outro lado, perante o corpo da mulher que é mãe, então, e por isso, a ser coberto, "protegido" e interditado. Segundo a blogueira, esse corpo não pode ser exposto porque deve ser abnegado, puro e

1. Disponível em: <www.vilamamifera.com>. Acesso em: $1^{\circ}$ ago. 2013 
dedicado ou, então, o "anjo consolador" do qual já argumentou Badinter (1985), enquanto o outro corpo, o feminino não materno, figura e deve figurar como fonte de satisfação e de desejo sexual, cuja nudez não seria castigada. É contra essa ideia que se insurge a blogueira, por isso escreve e circula sua imagem de nudez materna.

Na mesma esteira, Brum critica as rotinas hospitalares quando uma mulher dá à luz em um hospital, ou seja, a raspagem dos pelos e o corte do períneo. $\mathrm{Na}$ realidade, as entende como atitudes de repressão à nudez do corpo materno, do corpo que dá à luz ou que está parindo. Em sua opinião, quando a mulher não está a serviço do homem o seu corpo sofre interdição, porque considerado fora de uma suposta ordem. Essa nudez, para Brum, como bem aparece no trecho abaixo, é, ao contrário, um exercício de liberdade e um processo de dissociação entre sexualidade e "dar prazer a um homem", expandindo a ideia de sexual para além da relação sexual e da heterossexualidade compulsória.

Essa outra leitura de corpo feminino, entretanto, é ainda rara e pouco difundida, quando nos deparamos recentemente com a reação diante da amamentação em lugares públicos, episódio ocorrido nos EUA. ${ }^{2}$ Enquanto isso, de outro lado, a nudez da televisão, das propagandas de bebidas alcoólicas e dos automóveis persiste e é bem aceita. Para Brum,

os seios precisam ser guardados e substituídos por mamadeiras, devolvendo ao seio sua função não biológica de apenas ser um objeto de desejo masculino. A vagina poupada de sua função de parir estará apenas para servir à função cultural de dar prazer ao homem. Quando usada deve ser infantilizada (raspagem de pêlos ou tricotomia), seccionada (uma punição por desejar fazer uma função para a qual a sociedade não deseja, será cortada, costurada e carregará a cicatriz - episiotomia). Quando uma mulher se desnuda não para seduzir, apenas pelo exercício de sua liberdade, quando a uma mulher é dado o direito de parir naturalmente e sua vagina cumpre prazerosamente uma função que independe da figura masculina, quando os seios alimentam pelo prazer e biologia que contêm neste ato, há uma quebra de paradigma cultural. A mulher retoma o prazer em suas funções biológicas e desassocia a sexualidade da necessidade de dar prazer ao homem. Essa é a verdadeira nudez, que, infelizmente, ainda é censurada dentro de muitas mulheres e pelo mundo afora. (Grifo meu)

Dessa forma, por um viés, a escritora sustenta a não erotização da cena fotografada anunciando a sua naturalidade para que essa nudez não seja mais castigada. Mas, por outro, também defende a possibilidade de tal nudez vir a ser um exercício de liberdade e de outra leitura da figura materna. De repente, penso hipoteticamente, não mais a da mãe pura e de corpo todo tapado, tanto que a imagem traz à tona a figura de uma mãe bela, de corpo bem desenhado e exposta nua ao lado de seus filhos. E, assim, por que não o corpo de uma mãe potência, no sentido de liberdade e de múltiplas subjetividades, e não o de uma mãe clausura?

O interessante é que, nessas tentativas de desconstrução de uma ideia hegemônica de corpo feminino, desponta também a ideia de que parir não é ou pode não ser necessariamente sofrimento e que, bem ao contrário, pode gerar prazer e satisfação sexual, dando margem à erotização da maternidade e do parto. Senão, sigamos por suas linhas no referido post:

Lembro da sensação quente, do escorregar daquele pequeno corpo pelas minhas entranhas. Eu estava ali, nua, fêmea, selvagem, desfrutando do prazer mais intenso que já vivi. Um longo orgasmo selou sua passagem para esta vida, quebrando com o paradigma de que nascer é sofrer. (Grifo meu)

Vale ressaltar que ideias e discursos semelhantes a esse têm adquirido representatividade e força simbólica na atualidade, na medida em que um número cada vez maior de mulheres, a exemplo de Brum, tem anunciado sensações corpóreas de excitação e de satisfação durante o parto, ao invés da dita "dor insuportável" ou "pior dor do mundo".

Nas tramas dessas narrativas sobre prazer ao parir e de outras leituras e políticas do corpo feminino que pare, também os médicos/as aderem a essa possibilidade, o que anuncia a circulação dessa interpretação. Carlos Czeresnia, ginecologista-obstetra que é médico do Hospital das Clínicas/FMUSP, por exemplo, é

2. No dia 19 de agosto de 2013, uma mulher, no Texas, foi repreendida pelo gerente de um espaço de recreação ao dar o peito ao filho. Segundo vídeo divulgado no youtube, com mais de 500 mil acessos, o gerente pediu "decência" a mãe que amamentava seu filho. Vale dizer que há uma lei no Texas que dá o direito da mãe amamentar onde bem queira. Para mais: <http://g1.globo.com/planeta-bizarro/noticia/2013/08/centro-derecreacao-proibe-mae-de-amamentar-e-gera-polemica-nos-eua.html>. Acesso em: 14 out. 2013.

É digno de nota também que no Estado da Georgia, nos EUA, no ano de 2011, a prefeitura tentou proibir a amamentação ao ar livre no Forest Park e que essa medida desencadeou reação de um grupo de mulheres. Essas mulheres ocuparam o parque e realizaram um mamaço (amamentação coletiva) e, assim, derrubaram o que então já era uma proposta de lei. Para mais: <http://www1.folha.uol.com.br/ equilibrioesaude/955709-campanha-nos-eua-busca-estimular-amamentacao-em-publico.shtml>.

No Brasil, recentemente, um grupo de mulheres organizou um "mamaço coletivo" no Museu de Imagem e Som de São Paulo, como reação ao impedimento de amamentar naquele espaço. Para mais: <http://g1.globo.com/sao-paulo/noticia/2014/02/mulheres-realizam-mamaco-no-misapos-mae-ser-proibida-de-amamentar.html>. 
um desses profissionais a sustentar o prazer no parto. É claro que a partir de sua grade de leitura, mas o faz, como se percebe do trecho de sua entrevista para a Revista TPM (2009): ${ }^{3}$

Os movimentos de distensão e contração do períneo no momento em que o bebê vai sair são muito semelhantes à sensação do orgasmo. E o cérebro interpreta esses estímulos neurais com respostas de prazer. O parto e o orgasmo percorrem o mesmo caminho neurológico. (Revista TPM, 2009)

E a questão parece despontar com mais fôlego e acendendo controvérsias e defesas de pontos de vista, sobretudo depois da chegada de Orgasmic Birth (2012) ao Brasil, documentário produzido e dirigido por Debra-Pascali. Nessa obra, um conjunto de mulheres americanas salienta passagens de satisfação corporal e de orgasmo ao parir, no que poderia ser pensado a partir da ideia de "erotização da reprodução" (Diniz, 1996). Segundo a diretora, ao longo do documentário, o parto seria uma experiência mais ampla a funcionar como porta de acesso para outras dimensões da existência feminina e, por isso, dever-se-ia tanto questionar a razão de sua medicalização, quanto insistir na recuperação desse evento potencialmente transformador.

Nesse sentido, longe de figurar como sofrimento, parir, em vídeos/imagens caseiras e obras cinematográficas recentemente produzidas, desponta como possibilidade de orgasmo e de satisfação sexual em geral. Ou então, em fotografias, como a nudez que não pode/não deve ser castigada. E assim percebo ecos entre o que nesse registro imagético se vê e as narrativas das mulheres dos grupos por mim etnografados entre os anos de 2008 e 2010, quando frases como as que seguem já circulavam: "Eu senti uma sensação muito boa na hora da roda de fogo" e "Eu senti muito prazer ao amamentar". Ou, então, de maneira mais suave: "Precisamos pensar que o orgasmo pode vir muito mais como satisfação no parto e que essa, sim, a satisfação, pode ser bem ampla”.

Orgasmic Birth, no entanto, dividiu as adeptas da humanização. Ao menos aquelas com as quais tive a oportunidade de conviver durante a minha etnografia. De uma parte, havia mulheres que valorizavam a ideia e a achavam perfeitamente possível, enquanto, de outra, outras tantas que discordavam, por entenderem não existir tal possibilidade, ou porque temiam que o parto orgástico se tornasse um novo "modelo ideal de parto" e que, com isso, se normatizasse tal prática, trazendo mais malefícios do que benefícios para o universo feminino.
Durante a pesquisa, tive a oportunidade de realizar uma breve incursão no universo do parto respetuoso na Espanha, ideário bastante semelhante ao que, no Brasil, hoje se denomina de movimento do parto humanizado. A ideia nunca foi comparar os modelos de assistência ao parto de ambos os países, mas, antes, conhecer um pouco mais da prática das enfermeiras obstétricas que, na Espanha, ocupam mais as cenas de parto do que os médicos. Enquanto lá estive, tive a grata surpresa de constatar que a ideia de orgasmo no parto lá também tinha guarida e ganhava adeptas. Uma artista plástica, Maria Llopis, de Valência, nascida em 1975, assim como Brum, escreve em seu blog "Desnuda, transfeminismo, postporno y maternidades subversivas"4 e, ao fazê-lo, compactua da perspectiva de que o parto pode ser um acontecimento sexual a ponto de desencadear um orgasmo. Seu modo de atuação e de escrita é, no entanto, muito mais radical do que o encontrado no Brasil. Trata-se de articulação junto a um coletivo feminista pós-pornografia, cuja ideia central é a desconstrução das ideias de sexo, gêneros e pornografia. Sobre a questão que nos toca neste artigo, assim escreve a espanhola:

- ¿Me explicas lo que es un parto orgásmico?

El parto se parece mucho a la relación sexual, desde el punto de vista hormonal, pues se presentan las mismas substancias, la oxitocina y las endorfinas, y también desde el punto de vista postural. Cuando se presencian las imágenes de las posturas, gestos y gemidos de una mujer pariendo libre es inevitable pensar que en las mismas hay gran similitud con las posturas, gestos y actitudes y gemidos de una mujer sexualmente excitada. Hasta tal punto es así que podría pensar se que el acto sexual en la mujer es una especie de ensayo para el parto. Posiblemente el parto se encuadraría mejor desde el punto de vista biológico como un punto culminante en la vida sexual de la mujer. Claro, toda esta faceta queda anulada en un parto medicalizado. Pero la mayoría de las personas te dirían que el parto duele y el acto sexual no.

Si, pero hace poco leí una estadística según la cual hace cien años el 60\% de las mujeres sentían dolor durante el acto sexual, hoy damos por hecho que se debía a motivos culturales o de represión sexual. ¿no podría estar ocurriendo lo mismo con el parto hoy? Sabemos que han existido culturas en las que el parto no dolía; y por otro lado todos los que asistimos partos en casa somos testigos de que un porcentaje, es verdad bajo, de mujeres, sienten algo muy parecido al orgasmo durante las últimas fases del parto. 
Llopis escreve sobre maternidades subversivas, sobre parto orgástico e "amamentação selvagem", mas também cria e expõe obras e intervenções artísticas concebidas a partir da relação entre tais assuntos, o feminismo e o movimento pós-pornografia. Diante disso, se pensarmos que essa interface pode ser interpretada como algo de vanguarda, Llopis parece contribuir para que ideias consolidadas de feminino e de maternidade sejam desalojadas. E para que, assim, outras acepções sejam legitimadas.

Pensando por esse prisma, o que, atualmente, as mulheres brasileiras têm narrado nos grupos de preparo para o parto e publicado no FB talvez também possa ser lido a partir de outra perspectiva de sexualidade feminina. No limite, o que se pode tematizar, em minha leitura, é a existência de outra interpretação de corpo feminino, não mais tido como aquele corpo frágil e a ser coberto, não mais como um ponto de vergonha e de desconforto, mas enquanto lócus e ambiente no qual o prazer se vê conjugado à reprodução, não pelo fato de a mulher tornar-se mãe, mas a partir de uma erótica que lhe é própria, antes excesso e completude. Um pouco à la personagem de Carmen pensada por Birman (2003), em Cartografias do feminino, como uma mulher senhora de si na busca de prazer e de satisfação.

\section{Espetacularização da vida e ausência de intimidade}

As imagens de parto veiculadas nas redes sociais, no entanto, nem sempre e não só circulam políticas do corpo críticas e supostamente libertárias, mas também outras, aquelas que reiteram padrões de controle e determinadas regras sociais. Nesse sentido, nos mostram não somente como as sociedades moldam comportamentos, mas como os comportamentos reiteram imagens de sociedade.

"Conheça as novidades do lucrativo mercado da maternidade" 5 era a chamada de uma matéria divulgada no jornal $O$ Globo que conquistou circulação no FB. O post causou comoção e comentários em grupos abertos e fechados que discutem parto, gestação e maternidade nas redes sociais. De acordo com seu texto, em alguns serviços da capital carioca existem atualmente os serviços de cerimonial e de "Cine Parto".

O relógio digital do corredor da Maternidade São Francisco, em Niterói, marca $20 \mathrm{~h} 11 \mathrm{~m}$. Lucas nasce cabeludo, pesando 2,910 quilos e medindo 48 cen- tímetros. Após ser examinado pelo pediatra e ter o cordão umbilical cortado pelo pai, é erguido pelo obstetra em direção a uma câmera instalada no teto da sala de parto.

Em outro andar, 20 pessoas, acomodadas num auditório chamado Cine Parto, observam, eufóricas, a rápida sequência de cenas ao vivo, numa TV de 52 polegadas. Quando avistam o bebê, levantam taças de champanhe e celebram o nascimento como se estivessem comemorando um gol. (Grifo meu; O Globo, 6 out. 2013)

Conforme a reportagem, cerca de 30\% dos partos que acontecem nessa maternidade são transmitidos ao vivo e a sessão de filmagem custa a bagatela de $\mathrm{R} \$ 200,00$ (duzentos reais). Para o "Cine Parto" instala-se uma televisão de plasma no quarto no qual mãe e criança serão depois recebidos. Enquanto não chegam, a família permanece no local assistindo, comemorando e sendo ciceroneada por uma cerimonialista, personagem que dos casamentos parece ter migrado aos nascimentos, junto com festas, quitutes, decoração e recordação do bebê. Em tais cenas, até música e bebida alcoólica ganharam espaço. Tudo para, quase instantaneamente, ser postado no FB. Ou seja, tudo para cair rapidamente em circulação. Circulam imagens e, com elas, pessoas, percepções e representações sociais.

Entre os 20 estandes destinados à foto e filmagem, uma das novidades é o estúdio infantil BB Art, que produz um videoclipe do dia do nascimento (o Cine Baby) por $\mathrm{R} \$ 2.400$. O trabalho fica pronto até 24 horas após o parto, para os pais poderem publicar no Facebook. É um vídeo para fazer chorar, define o fotógrafo e videomaker Bruno Barbosa, que migrou do mercado de casamentos para o de nascimentos em abril. (O Globo, 6 out. 2013)

Para um médico, entrevistado na mesma reportagem, entretanto, esses seriam os sinais da "desumanização do parto" e da vaidade que parece invadir as cenas de parto na contemporaneidade. Em minha leitura, percebe-se, com isso, como nascer e parir também se tornaram uma questão de mercado e de consumo, característica das sociedades atuais.

A gestante precisa fazer aquele ensaio fotográfico com o nome do bebê escrito com batom na barriga; os pais postam a ultrassonografia em 3D no Facebook e discutem se o rostinho parece mais com a mãe ou com o pai. Há toda uma indústria transformando o indivíduo antes mesmo de nascer. (Grifo meu) 
Nesse sentido, mercado, consumo e ausência de privacidade não parecem incomodar essas mulheres cariocas, que, segundo a reportagem, percorrem o Estado para parir especialmente nessa maternidade da capital. E assim o registro do acontecimento, que é desejado pelas parturientes e seus familiares mais próximos, se vê atravessado pela necessidade de exposição pública e de uma certa espetacularização da vida. Transmissão simultânea, celular, mensagens de sms e de whatsapp, televisão de plasma, home teather e tablets com o registro do peso e da altura trazem à cena de parto não somente a tecnologia, mas, sobretudo, a conexão com o mundo sem fronteiras, mediante a internet e o wi-fi. Para Silva (2011, p. 154), pensando a partir de Augé,

o que é interessante perceber, no entanto, é a radicalização deste "estreitamento" do mundo na atualidade, culminando, talvez, na produção de um espaço de "hiperconexão", de extrema mobilidade, que não mais se restringe às pessoas, mas que engloba, também, produtos, imagens, informações e, até, desperdícios. A nova constituição espaço-temporal, marcada pelo fluxo incessante de toda sorte de coisas e pessoas, implica a configuração de um cenário altamente desafiador que não pode mais ser compreendido a partir da utilização de referências, sejam elas científicas ou políticas, balizadas por valores como os de "estabilidade" ou "fixidez".

A matéria, entretanto, veicula um ethos e um conjunto de práticas bastante diferentes das encontradas durante minha pesquisa com as adeptas de outros modos de parir, em São Paulo, nos idos de 20082010. E, assim, pode anunciar transformações, contradições e novas configurações das experiências de parto na atualidade.

Durante o período anunciado, entrevistei e convivi com mulheres muito diferentes em termos de profissão, religião, conjugalidade, estilos de vida, modos de alimentação e práticas de autocuidado. Se distantes nesse sentido, não obstante, eram próximas e semelhantes porque conectadas à internet, portadoras de escrita e de uma certa criticidade, pertencentes às "camadas médias" e, em sua maioria, brancas e seguradas por um plano de saúde privado. Nesse sentido, pareceram-me próximas, mas também distantes. E isso porque não encontrei, como se esperava a priori, adeptas do parto humanizado necessariamente "naturalistas", "alternativas", "intuitivas" e "neo hippies", mas, ao contrário, católicas, umbandistas e protestantes; bancárias, artistas plásticas e advogadas; vegetarianas, veganas e carnívoras; esportistas e boêmias; urbanas e rurais; alopatas e homeopatas; casadas, juntadas e solteiras; e, assim, sucessivamente na pluralidade.
Para algumas dessas mulheres, a escolha pelo parto domiciliar era a melhor opção porque a casa representava o familiar, a segurança e a liberdade para gemer, gritar, chorar e estar com quem se quer. E assim o peso maior recaía sobre a intimidade e não sobre a espetacularização da vida, como aparece na recente matéria de jornal. Não que as mulheres que etnografei não circulassem nas redes sociais suas experiências e anseios. Não se trata disso, pois o parto em casa, da ordem do privado, era e foi, muitas vezes, depois, publicado nas redes sociais. Trata-se, entretanto, de uma prática diferenciada. Naqueles casos, dava-se à luz na intimidade e depois publicava-se o desejado e, assim, controlado. Já nas situações ora anunciadas, a cena de parto é publicada instantaneamente e não a posteriore e depois de uma seleção pessoal de imagens. E aí reside a diferença entre essas práticas de parto.

Diante disso, a ideia é refletir sobre o potencial das imagens que circulam e operam como narrativas corporais de saúde, de feminino e de cuidado, que, como se pode depreender, comportam direcionamentos e finalidades diversas. Em certas situações ilustram e reproduzem o discurso da exposição pública e da lógica do voyeurismo coletivo, típico das sociedades contemporâneas. Enquanto, em outras, podem desvelar políticas do corpo contra-hegemônicas, práticas de questionamento de padrões médicos e de controle social, anunciando mulheres que gozam ao parir; mulheres que convocam umas às outras para marchas e demandas públicas e políticas; mulheres que se reconhecem a partir de suas experiências e mulheres que se contrapõem à ditadura da beleza.

Em alguns casos, pela imagem aparece o requerimento de pertencimento a algo que congrega, enquanto em outros, uma exposição sem um direcionamento específico. Expõe-se ao outro para expor-se a si mesmo e, assim, em nome de uma singularização do eu acontecem transmissões simultâneas, as festas nas maternidades e os posts do imediato pós-parto no FB. Essa poderia ser a mulher do "espelho do eu", sobre o qual escreve Lasch (1983), ou da "tirania da intimidade" de Sennett (1988), na medida em que parece importar mais o investimento em si mesmo do que promover uma transformação social, política e econômica.

As imagens circulam nas duas situações, no mesmo cenário e a partir da mesma temática. Porém, cada qual com suas particularidades, que, por sua vez, as afastam marcadamente umas das outras, distinguindo situações, mulheres e estórias, em termos de propósitos e relação com o todo, enquanto algo que significa a parte. No primeiro caso, circulam imagens e circulam as pessoas, tecendo alianças e reciprocidade; grupos se constituem. Na segunda situação, pode ser que aconteça o mesmo, mas, ao que parece, sem propósito de transformação social, ao menos com relação 
à crítica da assistência médica prestada, perspectivas de corpo feminino e de violência de gênero.

\section{À guisa de conclusão: a imagem é "boa para pensar"/fazer antropologia}

Este artigo dialoga com e a partir de imagens ventiladas em redes sociais, jornais e outros espaços virtuais. Imagens essas também tematizadas a partir de minha experiência etnográfica sobre práticas de parto humanizado (Carneiro, 2011). Nesse sentido, ainda que tenha fisicamente "saído de campo" há alguns anos, penso que a pesquisa persiste, na medida em que realmente "nunca se sai de campo".

Se a temática mobiliza, o pesquisador sempre mantém contato e se vê atravessado por transformações, novidades e reviravoltas da questão. Penso, ainda mais acirradamente, quanto o assunto contorna o campo da saúde e das políticas públicas mais atuais em tempos de "hiperconexão", nos quais, mesmo não querendo, muitas vezes, tomamos contato, via internet, com fatos e acontecimentos em questão de segundos ou em instantes. Em meu caso não foi diferente. $\mathrm{O}$ assunto, a sua notoriedade social e a circulação no ambiente virtual me mantiveram conectada às cenas de parto, pensando sobre os seus desenhos e significados sociais. Por isso, me vi mobilizada a escrever a partir da circulação de imagens de partos, cenas de partos e de corpos femininos, e, assim, inevitavelmente, pensar sobre o seu potencial político e social.

Por isso, diferentemente do antropólogo que faz antropologia visual ou da imagem, me oriento pelo que dizem as fotografias, mas recorro, inevitavelmente, muitas vezes, aos insights e às narrativas de minha pesquisa de outrora. Nesse sentido, antes de ser uma especialista, me aventuro a pensar "com a imagem" ou, então, "a partir" dela e, assim, a tecer costuras entre o verbal, o imagético e o prático. E se assim procurei proceder foi por me ver interpelada a refletir com e a partir de tais imagens e, depois, por constatar que a fotografia pode, de fato, ser muito "boa para pensar"/fazer antropologia.

Em razão da antropologia se propor a pensar o social enquanto processo e em seu universo simbólico, enquanto ciência tem o potencial de perspectivar imagens, destacando quadros políticos, econômicos e sociais, bem como contextos éticos e estéticos operantes em determinados espaços e tempos, e refletindo sobre eles. Nesse sentido, a prática antropológica poderia ser pensada como dinamizadora da imagem, já que, por um lado, coloca a imagem em movimento, e, por outro, se vê interpelada pela própria ima- gem, que também nos faz pensar sobre a própria antropologia e fazer etnográfico.

$\mathrm{Na}$ realidade, ao recuperarmos a história moderna, percebemos que a fotografia e a antropologia nasceram juntas no século XIX. E a primeira foi, inclusive, um artefato muito usado por antropólogos para o registro de outros povos. Nessa época, no entanto, como se vê, era a escrita que tinha destaque; a imagem vinha como seu suporte, como o seu complemento e a ilustrá-la ou corroborá-la. Ou seja, quase nunca em primeiro plano. Para Grimshaw (2001), isso seria um paradoxo, porque, por um lado, defendia-se o "olhar etnográfico", à la Malinowisk, mas, de outro, negava-se a autoridade do "olhar fotográfico", o qual só poderia funcionar enquanto apêndice. Por isso, Mead (1975), depois da péssima recepção do seu Balinese Character: a photography analisis, em co-autoria com Bateson, teria criticado a antropologia chamando-a de "disciplina das palavras".

Nesse sentido, em que pese, nessa época, já existirem trabalhos antropológicos feitos a partir de e com imagens - como é o caso de Jean Rouch (19172004), extremamente reconhecido por seu trabalho com antropologia e imagem na África colonial -, é somente a partir dos anos de 1980, período de surgimento da chamada antropologia pós-moderna, que a etnografia com e desde imagens parece conquistar maior legitimidade. E, ainda assim, bem tardiamente ou de maneira menos expressiva no movimento do pensamento "pós-moderno" como um todo.

Em seu início, talvez pela influência da teoria interpretativista de Geertz (1997), sustentava-se a ideia de "cultura como texto" e isso poderia reforçar a atividade antropológica a partir da escrita e do dilema sobre a "autoridade etnográfica". Dessa forma, na reação pós-moderna no interior da antropologia, o debate girava ao redor de quem escrevia/escreveria e sobre como se escrevia/escreveria. Porém, aos poucos, abriram-se fendas para que os modos de produção da antropologia fossem questionados e pluralizados, dando margem para a antropologia visual ou antropologia da imagem e, assim, para outra figuração da imagem no fazer etnográfico.

Para Rechenberg (2012, p. 55), por exemplo, cuja etnografia trata da memória de famílias negras no Rio Grande do Sul, as imagens obtidas mediante a produção e circulação de fotos de família também são "boas para pensar, inclusive sobre a ética na pesquisa antropológica, foco central de problematização do movimento da antropologia pós-moderna. E isso porque, segundo a antropóloga, fornecem ao pesquisador a representação que um tem de si mesmo, que constrói de si mesmo e, assim, dá a si mesmo voz e lugar na produção do que tem sido denominado de "antropologia compartilhada". 
E esse seria somente um dos muitos exemplos, estou certa, que anunciam a fertilidade e os muitos benefícios da antropologia que pensa com e desde a imagem. No meu caso, o intuito foi refletir sobre a circulação de imagens, imagens de parto e de corpos, imagens pessoais e em grupos de redes sociais, para, então, problematizar questões muito caras à antropologia e à teoria social em geral, quais sejam: noções de pessoa, de corpo, reconhecimento, dádiva e reciprocidade.

Nesse sentido, vimos como a circulação de imagens de parto tem propiciado e difundido releituras femininas do corpo materno e do corpo grávido, alojando-os no registro do que é belo e pode ser exposto; do corpóreo que se faz político e resiste a uma gama de intervenções médicas e sociais; de inscrição para singularidade ou, então, pertencimento grupal, desenhando, assim, noções de pessoa na atualidade. Dessa forma, percebe-se a possibilidade de existência de uma figura de mãe não mais como sinônimo de abnegação, mas de multiplicidade de papéis e, sobretudo, de atividade, para nomear a si mesma, o seu corpo e a sua experiência... fazendo da clausura moderna aquela que tenho pensado ser uma figuração de "mãe potência", no sentido do filósofo Spinoza e, portanto, na esteira daquilo que produz e inventa a existência humana. E assim, uma prática de reinvenção do que se compreende socialmente por mãe, podendo, em última instância, situá-la também entre o sexual e o erótico.

\section{Referências}

APPADURAI, A. A vida social das coisas: as mercadorias sob uma perspectiva cultural. Niterói, RJ: EDUFF, 2008. AUGÈ, M. Por uma antropologia da mobilidade. Maceió: Ed. UFAL, 2010.

BADINTER, E. Um amor conquistado: o mito do amor materno. Rio de Janeiro: Nova Fronteira, 1985.

BIRMAN, J. Cartografias do feminino. São Paulo: Editora 34, 2003.

CARNEIRO, R. Cenas de parto e políticas do corpo: uma etnografia de experiências de parto humanizado. Tese (Doutorado em Ciências Sociais) - Unicamp, IFCH, 2011.

E onde ficam os direitos das mulheres no momento de dar à luz? Parir no Brasil, um problema de saúde pública. Revista de Direito Mackenzie, v. 5, p. 227237, 2012.

DINIZ, C. S. G. Assistência ao parto e relações de gênero: elementos para uma releitura médico-social. Dissertação (Mestrado) - Faculdade de Medicina da Universidade de São Paulo, Departamento de Medicina Preventiva, São Paulo, 1996.

Humanização da assistência ao parto no Brasil: os muitos sentidos de um movimento. Ciência \& Saúde
Dessa maneira, o parto enquanto experiência sexual traz à tona a possibilidade do orgasmo ao parir, da nudez que não deve ser castigada, da beleza e das formas do corpo da mãe, daquela que gesta e dá à luz. Nessa esteira, torna-se campo para "guerrilha" de feministas espanholas que avessamente usam a pornografia para reescrever os corpos femininos não mais na submissão, mas sim na autoria do próprio corpo, mesclando, nesses casos, sexualidade e erotismo, como vimos com Llopis. Há assim uma crítica do uso do corpo feminino no mercado do sexo, mas, de outra parte, uma valorização dessa dimensão do corpo da mãe, antes pensada como castidade e pureza. No limite, o parto e a amamentação "selvagem" aproximam esses corpos de mulheres, em uma conotação positiva, ao instinto que seria liberdade, ainda que se corra o risco de reificar categorias como natureza/cultura. Posto desse modo, não se trata de articular necessariamente sexualidade e erotismo, mas perceber que, em certas ocasiões, imagens e discursos, ambas as dimensões da vida social, se veem articuladas.

Mas, por fim, me vi diante da discussão sobre o próprio fazer etnográfico, sobre o seu "como" e "quando", sua prática, rotinas e possibilidades. E assim, dei-me conta, mais uma vez, do quanto a temática do parto e o fazer antropologia podem ser ricos para a tematização das questões de gênero e universo da saúde sexual e reprodutiva.

Coletiva, São Paulo, v. 10, n. 3, p. 627-637, 2005.

DUARTE, L. F. Da vida nervosa nas classes trabalhadoras. Brasília: CNPq, 1986. Indivíduo e pessoa na experiência da saúde e da doença. Ciência \& Saúde Coletiva, v. 8, n. 1, p. 173-183, 2003. A pulsão romântica e as Ciências Humanas no Ocidente. Revista Brasileira de Ciências Sociais, São Paulo, v. 19, n. 55, p. 5-17, 2004.

DUMONT, L. Homo Hierarchicus: le système de castes et ses implications. Paris: Gallimard, 1966. O individualismo: uma perspectiva antropológica da ideologia moderna. Rio de Janeiro: Rocco, 1985.

GEERTZ, C. O saber local: novos ensaios em antropologia interpretativa. Petrópolis, RJ: Vozes, 1997.

GRIMSHAW, A. The ethnographer's eye: ways of seeing in anthropology. Cambridge: Cambridge University Press, 2001.

LASCH, C. A cultura do narcisismo: a vida americana numa era de esperanças em declínio. Rio de Janeiro: Imago, 1983.

MEAD, M. Visual anthropology in a discipline of words. In: HOCKINGS, P. (Ed.). Principles of visual anthropology. 
The Hague: Mounton Publishers, 1975.

RECHENBERG, F. Imagens e trajetos revelados: estudo antropológico sobre fotografia, memória e circulação de imagens junto das famílias negras de Porto Alegre. Tese (Doutorado) - Universidade Federal do Rio Grande do Sul, Porto Alegre, 2012.

SALEM, T. O casal grávido: disposições e dilemas da parceria igualitária. Rio de Janeiro: FGV, 2007.

SENNETT, R. O declínio do homem público: as tiranias da intimidade. São Paulo: Companhia das Letras, 1988.
SILVA, I. M. Por uma antropologia da mobilidade. Revista de Ciências Sociais, Fortaleza, p. 154-158, 2011.

VELHO, G. Observando o familiar. In: NUNES, E. O. (Org.). A aventura sociológica. Rio de Janeiro: Jorge Zahar, 1978. p. 36-46.

. Nobres e anjos: um estudo de tóxicos e hierarquia. Rio de Janeiro: Fundação Getúlio Vargas, 1998.

Individualismo e cultura: notas para uma antropologia da sociedade contemporânea. Rio de Janeiro: Jorge Zahar, 1999.

\title{
Circulating images circulate anthropology: women, body policies and spectacle of life
}

\begin{abstract}
This paper aims to reflect about the notions of person, female body and sexuality as far as the circulation of images of deliveries is concerned, most especially in social networks. Thus, the imagery record drives the production of anthropology and operates as metacritics. At last, it makes us think about its own structure. Although it does not undertake a visual anthropological exercise, it derives from images and its movement to reflect on its own making of ethnographic. In these games of deliveries and women's bodies, there are lots of readings and female body policies that perform other images and display others already consolidated.
\end{abstract}

Key words: images, anthropology, childbirth, sexuality, person.

\section{Imágenes circulantes que circulan antropología: las mujeres, las políticas del cuerpo y el espectáculo de la vida}

\section{Resumen}

Este trabajo busca pensar las nociones de persona, cuerpo femenino y sexualidad a partir de la circulación de fotografías de partos en el mundo virtual, sobre todo en las redes sociales. De esta manera, tiene como fuerza propulsora el registro de imaginería, que impulsa la producción de la antropología a la vez que opera como metacrítica, haciéndonos pensar, en última instancia, en su propia tesitura. A pesar de no llevar a cabo un ejercicio antropológico visual, parte de las imágenes y su movimiento para reflexionar sobre su propia producción de hacer etnográfico, sobre todo, a partir de discusiones de autoridad etnográfica. En esas fotos de juegos de partos y cuerpos de mujeres, se ve la riqueza de lecturas y políticas del cuerpo femenino y del parto que conforman otras imágenes a la par que espectacularizan otras muchas ya consolidadas y todavía en vigor. En este sentido, la idea central es reflexionar sobre el género, el activismo, la crítica social, la salud sexual y reproductiva y la noción de persona en la contemporaneidad de lo que se ve en Internet, pero también a partir de lo que se lee y ya se escuchó. Pensando a través de otros lenguajes e idiomas.

Palabras clave: imágenes, antropología, parto, sexualidad, persona.

Data de recebimento do artigo: 30/1/2014

Data de aprovação do artigo: 15/12/2014 